University of Louisville

ThinkIR: The University of Louisville's Institutional Repository

Electronic Theses and Dissertations

1948

\title{
A case study and the justification of a unit-type program.
}

Maxine D. Fruchtenicht

University of Louisville

Follow this and additional works at: https://ir.library.louisville.edu/etd

Part of the Educational Methods Commons

\section{Recommended Citation}

Fruchtenicht, Maxine D., "A case study and the justification of a unit-type program." (1948). Electronic Theses and Dissertations. Paper 2042.

https://doi.org/10.18297/etd/2042

This Master's Thesis is brought to you for free and open access by ThinkIR: The University of Louisville's Institutional Repository. It has been accepted for inclusion in Electronic Theses and Dissertations by an authorized administrator of ThinkIR: The University of Louisville's Institutional Repository. This title appears here courtesy of the author, who has retained all other copyrights. For more information, please contact thinkir@louisville.edu. 
Untresedty of Loulerille

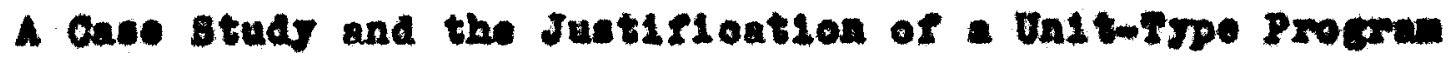

\author{
A Proroseloaal Paper \\ subattod to the raoulty of the Graduate \\ Sahool of the Uniterelty of Loulerizle in Partial \\ Fulfilimat of the Requiroments for the Degree of \\ Manter of Eduoasion
}

Bopartinent of Education

Haxine D. Frudatend

May 1948 
NAME OF STUDENT Maxine D. Fruchtenicht

TITLE OF PROFESSIONAL PAPER: A CASE STUDY OF A UNIT TYPE PROGRAM

APPROVED BY READING COMITTEE COMPOSED OF THE FOLLOWING MEMBERS:

Hilda Threlkeld

Ruth Dunn

NAME OF DIRECTOR: J. J. Oppenheimer

DATE: Mmay 124,1948 


\section{Aoknowlodgmate}

The woter whos to exprese her doop eppreolatlan to Dr.J.J. Oppenhelevr, Deas of the colloge of Liborral Arts, Galverasty of Loulerille,

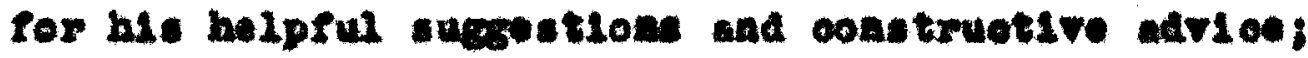
to Dr. HLlde rhrelkeld, Doun of Fown, and Hoe Ruth Duan, Jefformon County Bupowleor of Blematery Bohoole, for roading and oritioluling the manueript. 


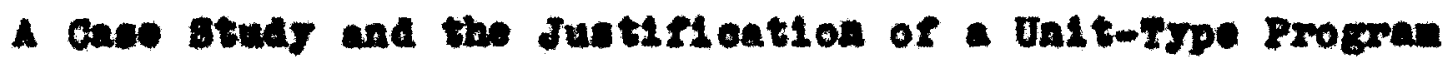


Table of Contente

Poreword

Pass

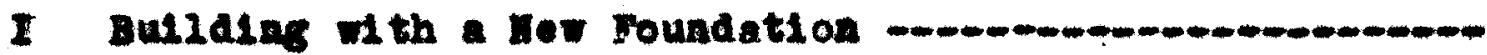

I The Porohlatr10 Approaeh -

2 The Iov PhIlosephy _-

8 Tho Artiat1e Teachor

II A Cace study of a Unit-Trpe Leseor -

Provedure - H1fe In Egrpt - 13

1 Early Bullding $\ldots \ldots \ldots$

2 Axolent Arte and Orafte -

3 A Caraven Irip - 16

4 Egrptian Writing -

- Rguptian Faralug - - 18

6 Culminatlag Aot1rity -

IXI Justifloation of Unst - 20

1 Unit seleotod

8 Approsoh to the Unit - 28

3 Group Wort 1n Organisation -

4 Liboral Dleouseion in Groups -

1 Tripe -

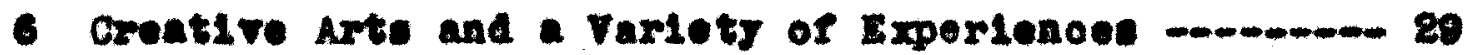

7 Comandty vee - 33

8 VLual Education -

- Culnlaating Aet1V1t100 - 37

10 Criteria for Evaluation Aotivition 30

IV Conoluedon m-n-m 1

Blbliography - 
A cane stud of a Uat-trop Prograx

Forowort

Thle peper w11 not interest the experienced teacher. It is not witten for hor. It is writton to chow bow a trpleal unt progran, taught by any tosobar who has fatth in the celwatere process, oan fulf121 all the socopted requiremente in the t1eld of oduention,

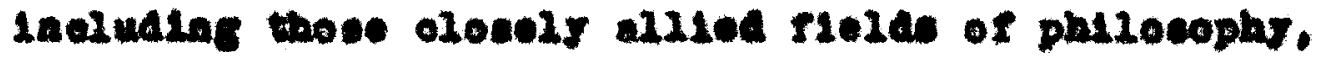

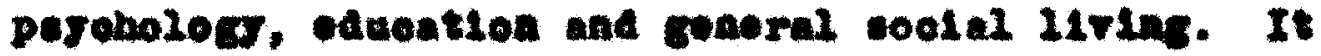
1. doelgnod to ohos the novioe tho le Just boginalas

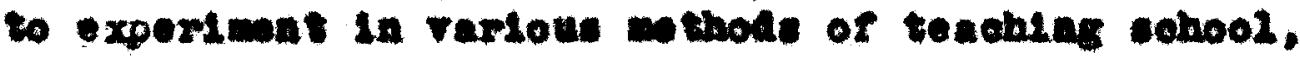
the velue roel vod from colng a oreative plece of work wth shis wethol. It is mitten to maver coso of the

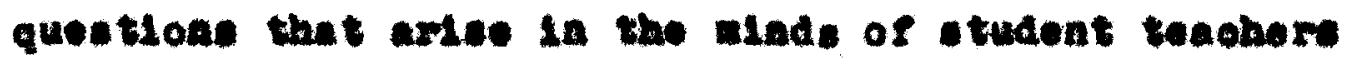
arter obserrias thie progran le cotion. It la a plea for at leat a triel for tho wothod, and hope that $1 t$ w12 awaten the otudent to want to exporinent in gxoup

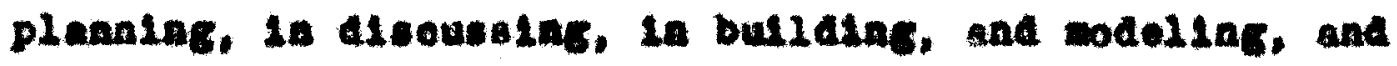

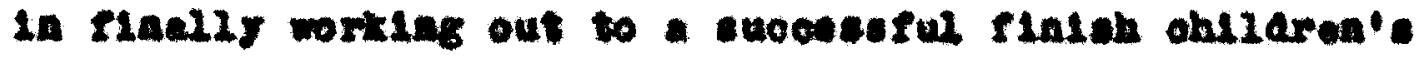
problew insteal of a cerlos of tondher's loseons.

Thow $\mathbf{1 1 1}$ be cage of alscouregement, frustratlon,

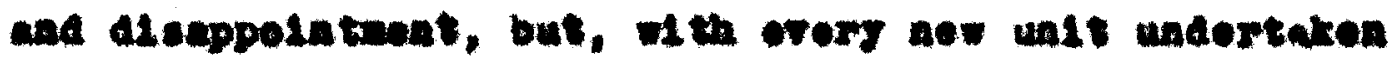

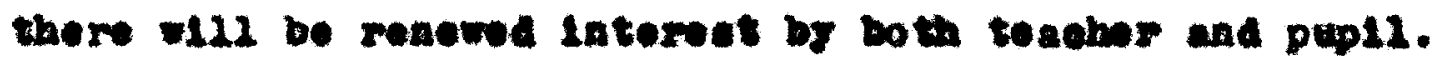


Then your troublesone ohliaren eppetally your upper elementapy boye have beone attendano probleme, and bohavios problen, it is well to have a tact or a roponelblilty glten hin in a group. If rou are clever enough to Ind conething he oan wally do well, whothor 1t 1 to bu11a, to model, to read, to camre, to be the eleotriolan for the alues theatr, to hare cone job that he alone oan do better than anyone elae in the roon, you have won thls boy, and he w111 be eager to work and do he part in h1s group. You 111 have any catiefying expmples of a destro to cone to cohool and you w12l Ilad to any it is a good place to bo; a plaes whore the Individual is a worthinile pereon, whoro he 1: appresiated, wrore ho is noeded in his 8roup, and were sriendilnoes provalis, and haroh ort tioler and faliure 10 uninom.

Then how about the teacher. Thare 111 be 1 ede boxedon experienota. Sow tines there w121 be more phrolonl exhaution, I grant, but rou just oen't becomo plaela and otale and borod, when thirty-rtro eager ohliaren are lnoluding jou la tholr plano. I lnow beause arter twenty yeare of trial and erros In all nothode, I have boow a oruender for this novewas, and thl paper is urtten in defenes of the und t-tjpe progren. 
Chapter I is doroted to a roview of the wew gocle

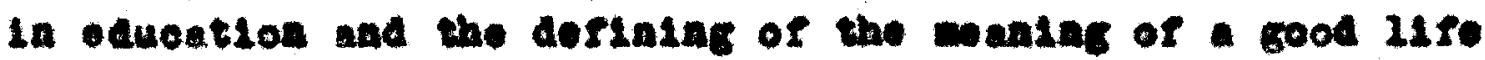
In the doworatie prooses. In Cumpter II, I have recorded the procodure in alelogue es ase etudy to thow the part played by the teabher in gulding the ualt. In chepter III, I have tried to prove that the reacon bohind the wethol 10 sound as given by the coopptod outotanding leacors in the

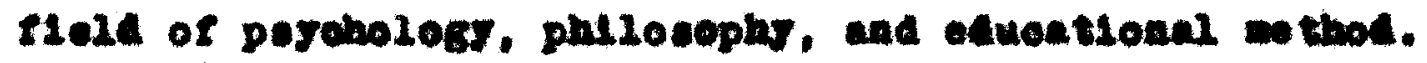
Chapter IV cires the oonoluston of the unts. 


\section{Chaptor I}

\section{Bullaing with a How Foundation}

\section{The Parohlatrio Approaeh}

Fron our atudy of pajohblogs we bellere that learning 10 the noet 1mportars funotion in the dovelopment of the ohila; and, the nost 1mportant thing to 2onrn 1s to got along 1 th other human belnge. The cohool mut gulde the "foellag" of a onild. For how he Ireele" about oertala thlage w111 be repleoted in ererrthing ho does. H1. foelinge on mattere of soolal, bexual, and work conditlons must be guldod.

If wh have the Mght $0001 \mathrm{al}$ relationshipe W1 th our fanilies, our Irlende and our nelghbors w are happs. Thle problen of "foellage" 1s tlea up with the f1eld of mental hrgion, but it is largely oommon sence appliod to oreryday 21ring. A $\$ 011$ balanoed $11 f 0$ that has a purpose 18 a happs 1180.

Children, as well as tenohore and all othor people in this old world want to be happs. and the nost pleasure in l1fo cones fron working with, of for each other. 
The sohool then wust eupply the environwent and the teachers who w1Il holp the ohl2d wet thle problen. By working together, planniag togothor, thinking together, playing togethor, or just plain 11riag together, eolving the little probleme, that wone day w112 be blg ones, a oblld W111 grov and leara cooperation. Aad, we be goes through this every day experience, it 10 hoped that he w11l bul1d a ph12000phy of 11fo by which ho mar $11 \mathrm{re}$.

2. The How Phllosophy

If thon, thls 1s our bellef, if wh have formod for oureelvee such a phlosophy, what a ahallenge it holde for teachore.

How many toaghere are otill trylng to f1t squaro pege into round holes and round poge into equare holeer mis do not intentional, but 1. Aw to the seant Information avallable for teachera' collogen in the 21eld of watal hyg10ne.

Instend of forelag our ldeas upon ohlidron, wo should try to tall over our problens and our differenoes with thon. The now eduoative prooess 1. one of charlag, otchanging 1doas, fratornallatug and questing for truth. Teachera of the old sobool with text book reol tationleft out this expat rapport of 1deas. 
If we chare our vlew with lore and Sraternel detotion, wo w11 elowly coe omerglac. this new eduoative procese. To wuet toakh ohlidren to think, to disouse alferent, poselble

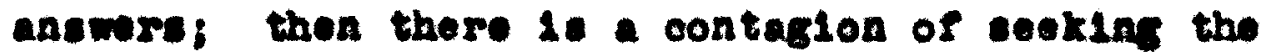
truth, and wo begin to foel that this is the good 11fo. How oan wo boet devolop thl atmoophore in tho sohool roont How onn we get ohllarsn to seek knowledge on thedr own laltlatire, to 60 to the 21brasy and browes around hunting laformation, to Inquire, to bulid in malature Inventions and ropeoduetzons, to model and earre, and to orvats oharaotere, soenes and storles to tell to othor ohilarear how oan wo got then to liaten pationtly and wh th an open nind, to tee the othor follor's polnt of viow, then altor his riews and think through the problen again arolalns all angles of oonfliot.

Far elghtod oduoatore, and phdionophere sav the groet adrantage to bo galnod by menklad In thle new disouselon type progran, and wanj now we thode were ceriese to Introduce this plan into the cohool.

Bone of the nehtods Introduad at tho tura of the contury have been known by rarlous nanes suoh as the projeot yesthod, the Aotivity Progran and tho Ualt Plan. It is the latter that has interested the writer and promotod the oaso 
study found in chaptor IX.

B. The Artiotie teacher

Teaching, as in anj other endeavor

In human 11fe, 18 made up of all kinds of people. There are 1 gorous and plade toachers, energetio and Indolent toachere, open minded and olose minded toaohors, utagnant and progroselve toachore, areamers and praotioal toachors, and orude and artietio toabhore. To oarry out a oreative pleoe of work, so deatrable in the new type teaching, requires an artiotio teacher. She wust be healthy, pleasant, eathuslastio, well Informed and an enotionalis adjustod Individual, w1 th a concloue piniloeophy of the type of the type of equoation sho is otriving to "put orer". The alass roon 1 teels nust be cloan, noas, attraetire, and adequate in order to provide the right atmosphere. It 20 of utuost Importanoe that the teachor uses her knowledge of the colldren's abli1ties, Intereste and natural proalivities 12 sho 14 golng to do good job.

Creative toaching requires an onthusiastio teacher. Cnlldren are rigoroun, aotive, Imaglnativo and unthusiastie, and thoy respond to adulte who chare enthusias:. 
The artlat teacher knowe that "how to do. 1t", 1. Just as 1mportant as "what to do". Art1stry moans that something has been added to mere routine or were adequaer, it meane Plnesse, aparkle, a glese of humor, a deft disorinination and a warm kindilnese whloh convinoes erery ohlla that the teacher w111 stand by hil whon all othor friende rall.

It 1s a well known faot that chlldron aquire the1r tastes $2 n$ muelo and art fron tholr teachers. Thoy also acquire hablts of cook housekeeplac, orderlinese, eqquenos, work and responsib111ty fron the wanner in wioh the sohool roon aotivities are direated.

In the Ualt Trpe progran the artist10 teacher has a wide fleld to praetloe all the arte of teaching. Here ohe way see the oreative enorgtes of her ahlidren unfold and see thom blosen into happy indiriduels under bor exillful guidan 00. 
andeter II

$A$ Case study of the UnIt-Trpe Plan and Ite Juetifleation

Prooeduse

I Introduction to Undt:

$A$ Vee of the Bulletia Board

1. Plotures of caravans, oamele and an oasio were placed on the bulletin board. Children comanted thet we must bo golng to study about the desert. The plotured wore plpladed by pletures of calro and $21 \%$ along the III0 Rirer.

\section{B vec of Plotures}

1. The teacher' 001 leotlon of plotures were pastol on unifore mounts and wore pased around the roon and lator exhlblted. The ploturse Included ell phases of Igrptian 11fo that the toacher expeoted to oorer 19 the study. There were plotures of 1rrigation wothod, the sphinx, tho prranlds, EgJptian farming, boate on the Hile Rlvor. date palne and oaels, ploking sotton and othere. 
1 Procodure:

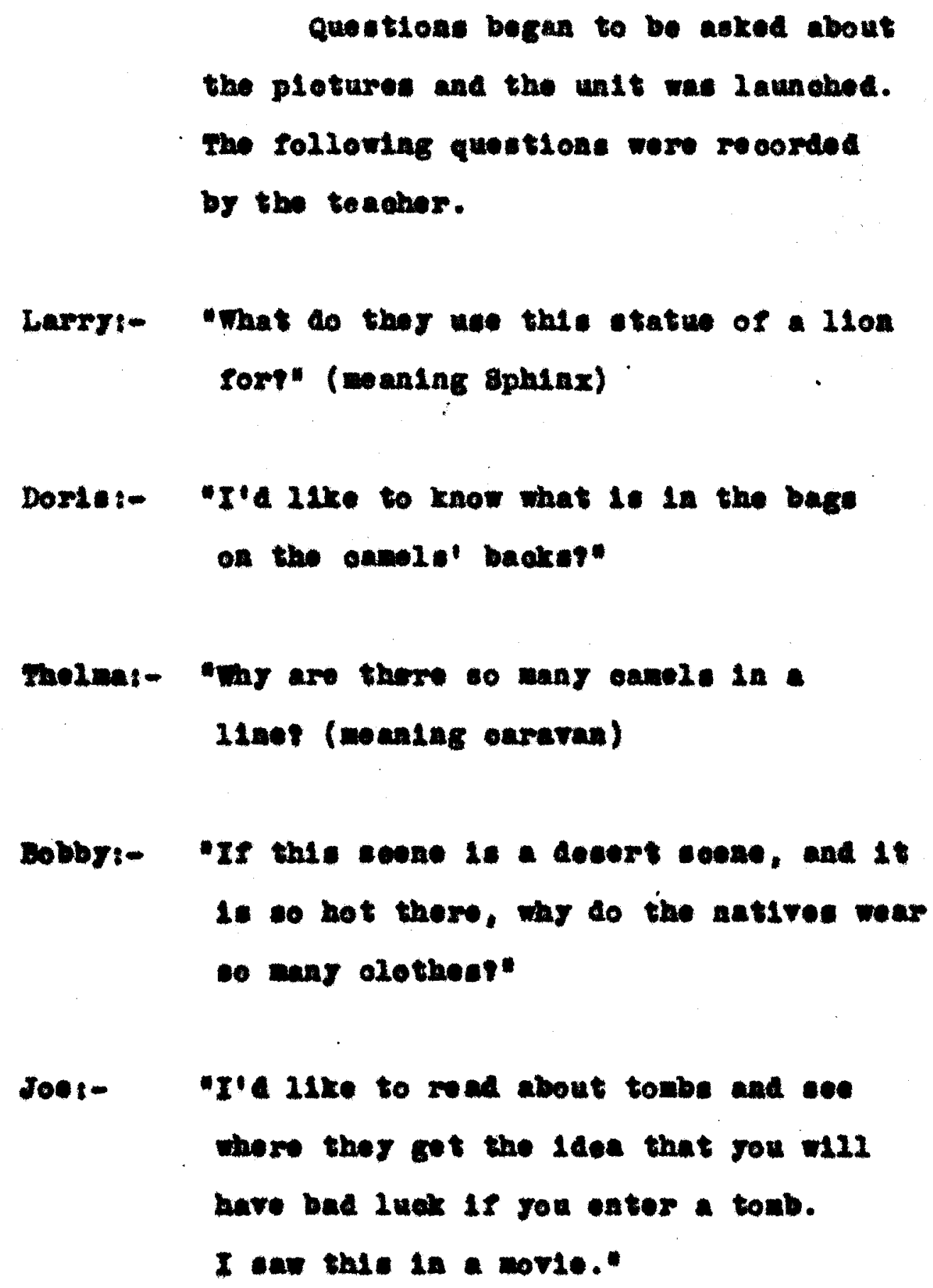


Carolmi - "We haven't seen anjthing of thelp food. mat kind of food do they eate"

Mrani- "Why con't the Isypt1ane use tractore inotead of stleks to broak up tholr ground"

Donerif- "Mll the orope are cotton. Why do they ralso so mels cotton?"

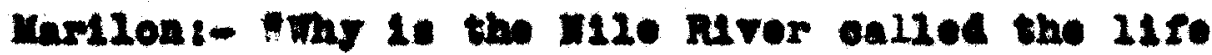
11ne of Egrett"

Elnore:- "What is an oagter"

Jack:- "How oovd a klas bulld a prrantd in M. 1150 tim, if it took wo long to 11ft just one etone? Are thoce wan anver"

Donald:- "That 10 In a tombr Are there any tombe In the Undtod stateer"

Rencer1:- "If 1t 1t wo hot thers, wh do they have so for windowe in tholr homes on the odelet mat are these howes nace orf" 
Dobby:- "That all woula you see if you wow
- touriat rialting Igrptr I man arferent thlage than wo have here."

Tomn:- "Do they hare a k1ag or a prosedenty"

Larxy:- "0asro looks Ilke a nodern ofty. How ala thoy know how to bulld oner"

Charles:- "Do ther belleve in our Godp"

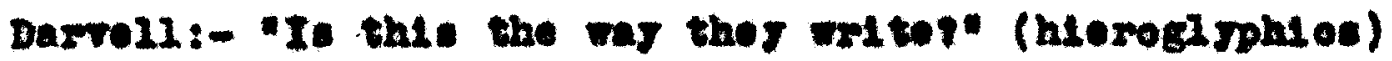

Towny:- "Do wo do anrthing the way they do its I wean do we opy arter thon in any way"

Toaber:- "Your quotione ar TerJ laterentlac and I wourd Itre to know nome of thene anewert, too. Lot we try to eroup the quostions under ceveral broad hoadinge. That ahall w eall thont rood, sholter, cooupations. trade oustono are rers good. Mhink throuch the toplo you are interested in and aode whe grow gou profer to work ath. Lot un noninate and roto for growp enptatas." 


\title{
Procedure
}

I Organdenton

\author{
4 Dionuelon Perlod \\ $I$ Grow 1 Early bullalas

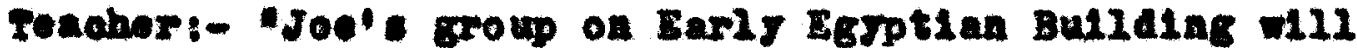 \\ neet wth the reacher." \\ Jos i- Wa11, we hare 10okn through al1 of the booke \\ on the mexervice tuble and have nace up com \\ leadins quetione wion we w11 ues as oup \\ calde. Th have al go nndo ous bibliography. \\ Eore aro our questione:- \\ 2. Won ald the Egrptian worohtp and wing \\ 8. Dow 4a they honow thels gode and wols \\ reseger \\ 3. Dall comothin about theletpirde of \\ arohtecture. (I win the ues thet ade \\ of the buntesu colvane.) \\ 4. Doeeribe the gphing and were 1018.

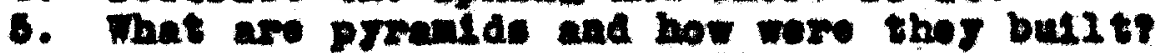 \\ 6. Ibat we coopatra's doedet

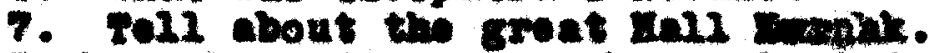

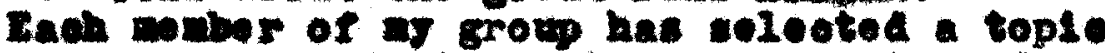 \\ and we aro reaty to und te our reports and \\ bulna aur oxthet."

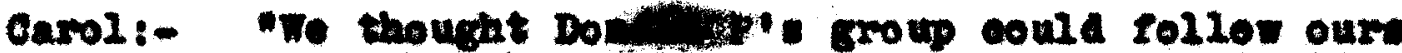 \\ and then be could bhov that we round inclde \\ of our tonbe. Fo woula like one neeting wh \\ his grow. \\ Teacher:- Yoe, olnoe he 10 golng to nate the contents \\ of a toab for his nueven, I thint jou two boye \\ oertalaly bould wort togothex.

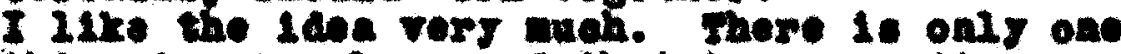 \\ thing to ronomor, and that is proportion.

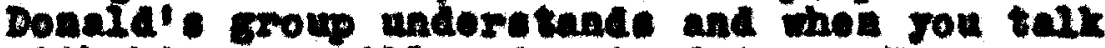 \\ ath hil fou 111 undorestand too. Your group \\ 10 alent sove."
}




\section{Procodure}

Orcantsation

4 Dimouesion Period

I Grop 2 Anclest Arts and Grat to

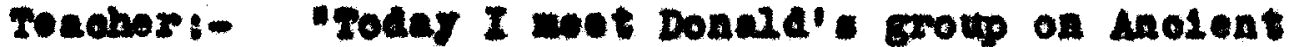
Arts and Grate. Ios are rou progreselns

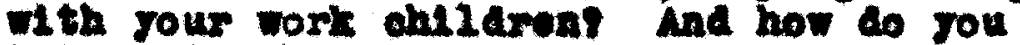
Intend to bow jour Laformation?

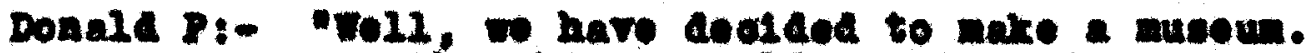
Wo thought w oould odel, and onme, and conetrues wapene. fural ture, potbor. and Jowary, and put a tory with dion

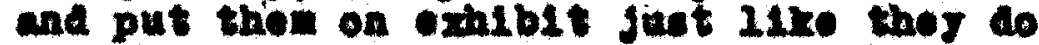

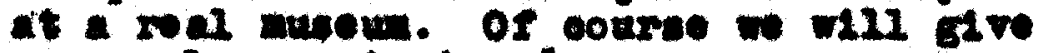
ons ored roporte toe."

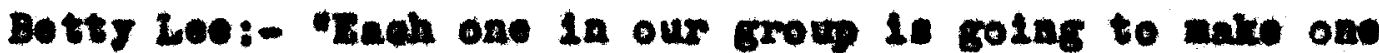

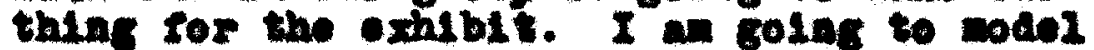
the bowle and alines that they use. I elpady have the pletwee to une and a etory so ro inth the posterr."

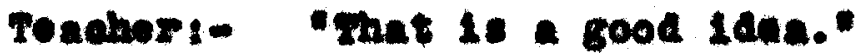

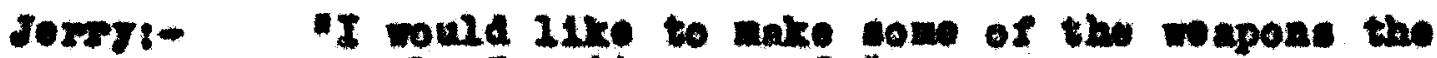
-aris Revptian unsa."

Joann:- ol an golng to got a doll and oover hos wth - tripe of oleth and put ber la a mump oace of fine. I woula $11 \mathrm{re}$ to write an inno

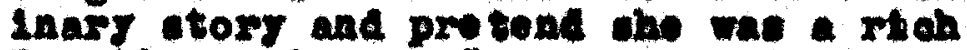
Egrptan princons."

Teadher:- "Don't forget to stad out hor the boales were provermel, Jounn, and why they are ot111 round the r.

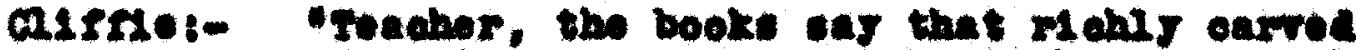

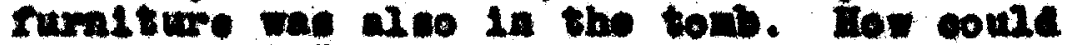
Ther these

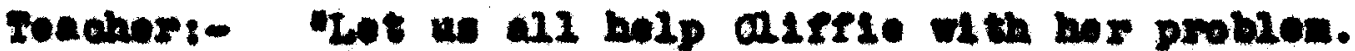

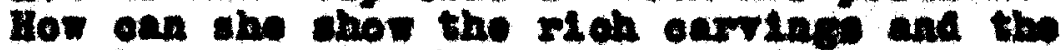
Jowl lalaye on the curaltures"

Axing:-

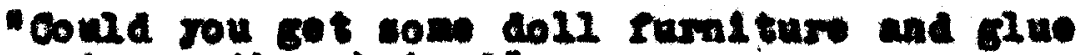
cete on the aminere

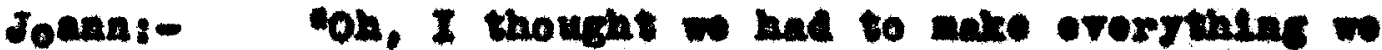
had in our exhibs." 
Toacher:-

Iroman:-

Tonohor:-

Donala P:-

roacher:-
"Lot un talk the oror. What do rou thint woula be the best way to shor this phase of tholr 11 fer what would we aced to keep in alad in this oxhiblt bosddos mating it as true an we cant"

"You know I was Juat thinking, wo coulan't use that doll rurniture arter aly, $1 t$ would be too 11ttie for the aumy. If the woll Joann uese 1s trolve inches tall our furalture would have to be the right eles for bor."

"roe Rran, you have montionod polnt I was thinking about. This is oelled proportion. Ererrthing in jour exhsbst wuet look right ith the other work."

"urs $F$, woulde't it be fine if wo could ake a glase cais and put our exibit in it just ilie teal one. I bellere my daddy oould got 20 the clase."

"Bonald, your 1dea Io excellens but that is your problen and 1 it 1 up to you and your. group to nake 1 t as laterosting as posalble. Now elnce rou have all of rour plani roaly. briag in tho naterials you $\times 111$ noed from home to corrov and you nay begla. tho group 18 aroulesed." 
Proooduro

I Orcandention

4 DLeousefor Perlod

$I$ Group 3 A Gararan Trip

Teaber:-

carolja, 7111 jour group woot wh the this morminge Row is our caravan trlp contage"

Carolja:-

- Te can haraly walt to got otartod Mre. F. Iy grom at yenterany arterno on at in house. Wo mat to olariedale Library and found fire books. Te thought a puppet ahow of a trip in Bejpt woula be a grand way to show the people the oftied, and trading."

Teaduer:-

"Do rou hare ar lind of a workable outilnet"

Carolja:-

10e, we thought wighe how:soone I - Proparine for our trip

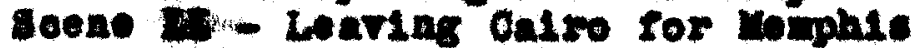

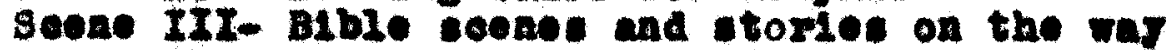
Geone IV - Tradi on an ourle."

Toahe r:-

- glnee rou pepple hate had oxperienes in nuling puppote rou may bogla on your work. Romiber rou nuet have orergthing wil orchn-

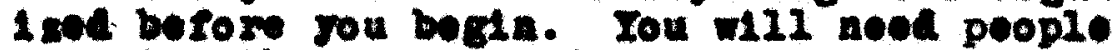

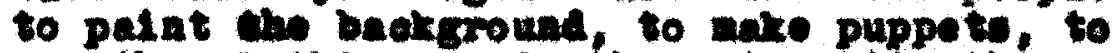
con the elothinc, and others to wite the aldero."

6aro27a:-

"Yoe wo know what gach one 1e golas to do."

Teadher:-

Eow do gou propose to chor jou ere sotunly travellag into the cenerte"

Boxothy:-

"Br ohanglas our coones we on bhow 1t."

2useher:-

How about drawing jour eanes on roller curtala and, as rou tratel lond along nore the coese to $\mathrm{f}$ tre the expet of paselat object."

Patsiola:-

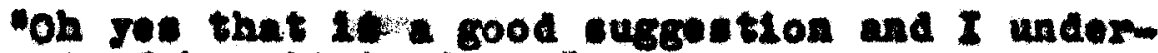
etina how it is done."

Teadior:-

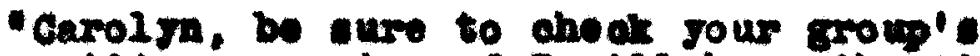
witten reporte and I w11 hear thoi tonowrov.

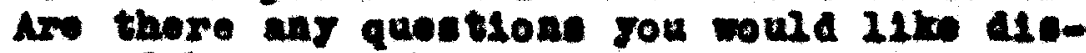

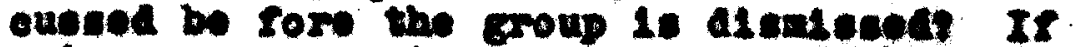

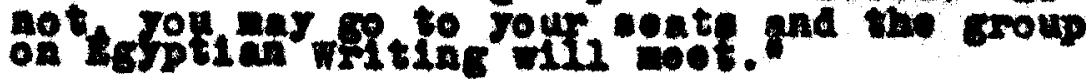




\section{Prooseduro}

I Oryanisation

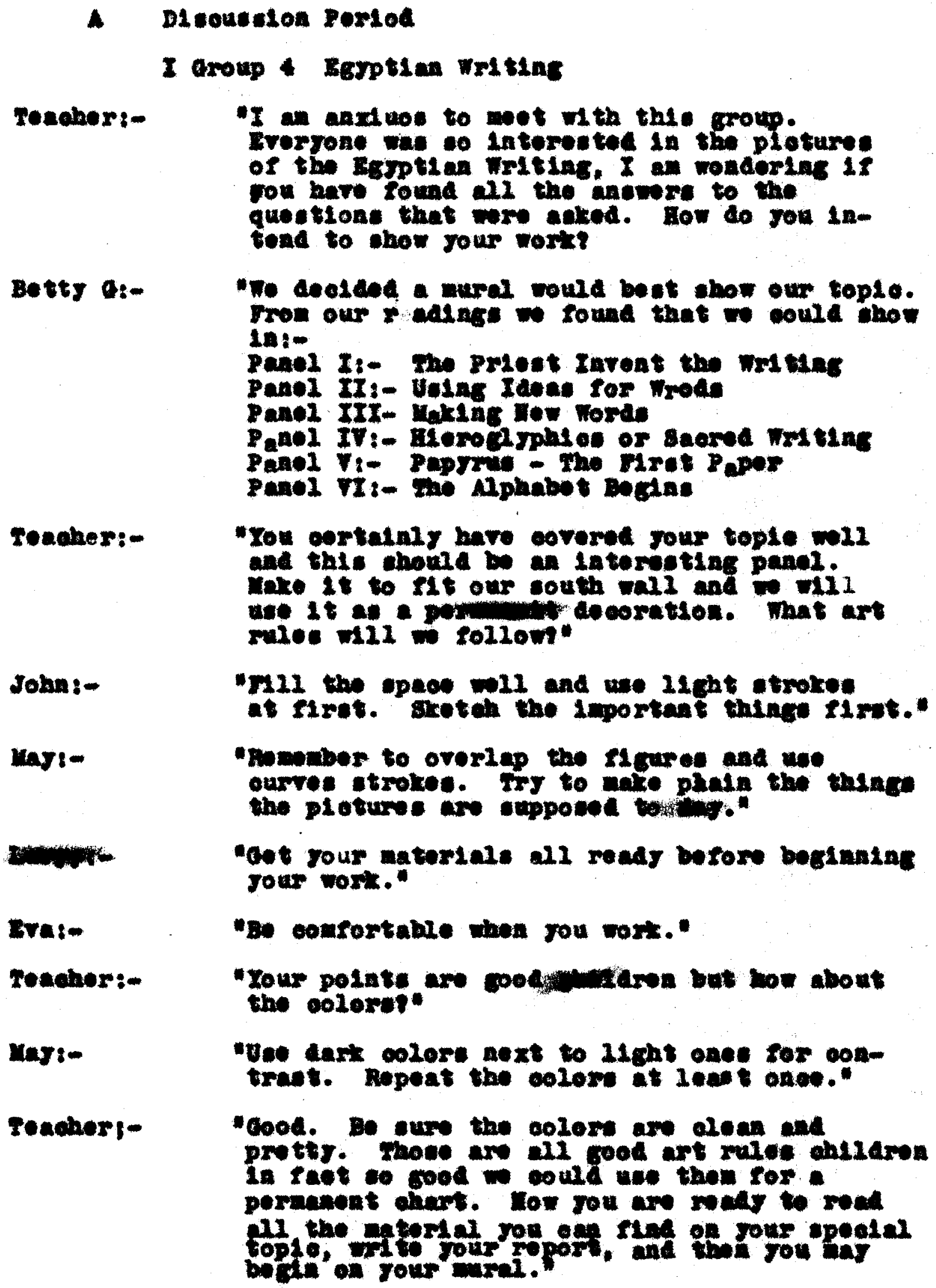




\section{Proosane}

\section{Organisation}

- Dieneuton Partod

2 aroup 5 Eaposan Farning

Tonaber:-

air :-

Doretar:-

Bobbr:-

Wender

Babbr:-

teaher:-

Dobbr:-

Ruth:-

Tendhes:-

Toning:-

Teacher:-

Con2:-

2enderer:- "aroup 5 w11 not this noralag. Let us tall bout the wort you buve boen dolns.

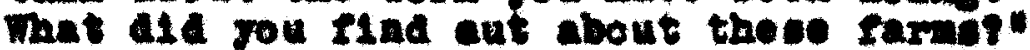

II wad that the cotton there is rory good wth longer 21 broe than oraluary ootton. and that tho ous she ootten in thos? onftune when they plat it."

athe farmere apond on the H120 to orornow, but atwo the 2100 ther 10 a ary opel1 and they wuet ixmgate the Iand."

thoy wore the Mret people to basla

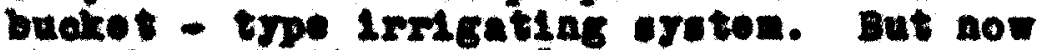
ther have bullt ande."

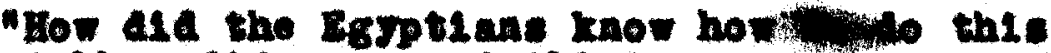
Bobbr. ala rou rona thiot

tos. the Ingle holpod thon."

"I wonder wh ther belped thong"

I gues so thes coura rales nom cotton."

- I rad that aearly orery Sand2y mas wors all an long arelns the ary apoll to pump water into the ir riezan."

"Ios, and wo want to ILA out wh theg don's have pump $21 \mathrm{re}$ have in inerlen."

wher une ctidic to oultirate tho coll and ctil ne butralees to turn the water wasele. I ooula arte one of these buaket ujetrone."

"I think that woule be intreresting."

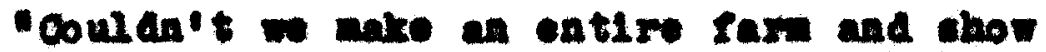
cons of the thinge we hare ben taxilng abuse:

Iov, arter wore monding jou w111 be maly to xport and to conetruet jour rarm." 
Progenary

I organdsotion

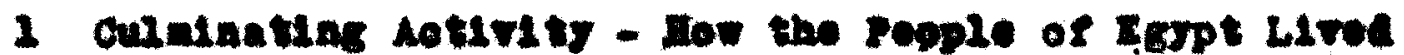

Teacher:-

"Today wo are hopp to have so anay of our

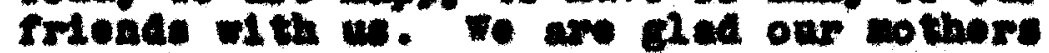
wro wbe to ootis. Arter the progten you

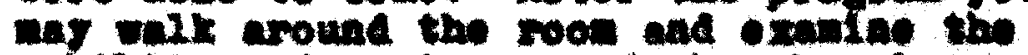
exhibite and plotures vad by the alase. I w1I now turn tho progrum over to jos tho will introduos ede croup."

Joe:-

"Tho rimes pereoa on our progran 14 ponald 7. if w21 ctive the Iatroeuption and how us bers ow unt takes place."

Donala I:-

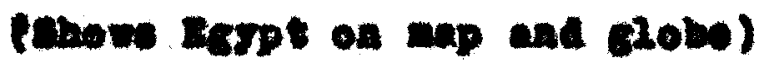

Arter the Introduotson onch grow eaptain cone formand and gove his procria

rals to the progrent-

\begin{tabular}{|c|c|c|c|}
\hline Grev ne. & costrin & Desed & Swatre conctruttion \\
\hline 1 & Noo $\mathrm{L}$ & Farry Buscatas & and \\
\hline 8 & Donala? & $\begin{array}{c}\text { Macient arte and } \\
\text { Orefte }\end{array}$ & \\
\hline 3 & carolsa $\mathrm{X}$ & 4 Coraven Ixts & $\begin{array}{l}\text { A puppes show horing } \\
\text { trade in Eesp }\end{array}$ \\
\hline 4 & Botsy 6 & Espotala wrtans & Das the \\
\hline $\mathbf{8}$ & $\operatorname{can} 2$ & Sopten Famia & 18 of $\mathrm{Egn}$ \\
\hline
\end{tabular}


Chapter IXI

Justiriontion of Onit

1 Ixplantiont-

In say unit it is whe to hore a "matr", full

subles that w111 corer a was rarlety of toplos. One that lacludos gography, history, and the arts is alware doelrable.

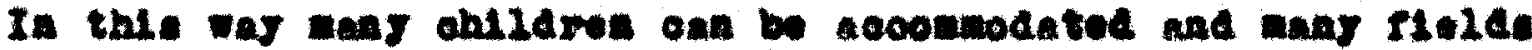

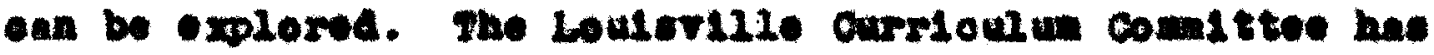
chosen the toples for study in orades $31 x$, weely, and overy wis fulfile these requirimonte.

whon a unt has boen oboesn or whos it is procoribed by a ooures of stud the teacher nuet wet the stage

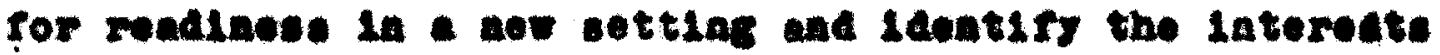
of her puplle in achering the dostred objectives. Tho toacher wut have an overvios of the untirs und olearly

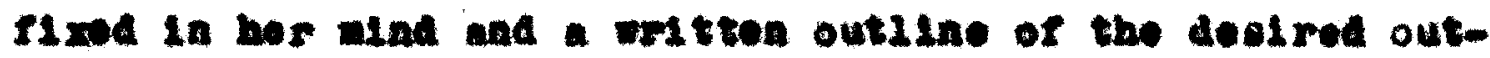
oowas 1s costrable. Is this one Eorpt, the cracle of

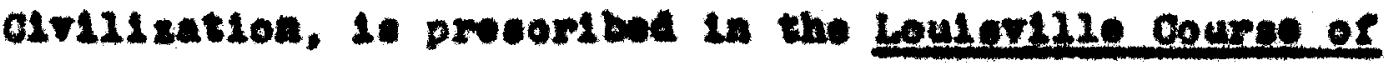
Study for the sixth Brade, and the orexvione and outcowe axv aloarly stated. The unlt-plan bas four waln toplos nenely:-

Iatroduetlon, Orlontatlon, Orcaniention and oulalanting sotivitios.

II Juetstioationi-

- Bariy in the soolal studion ourrloulur otudy progran. the tenebore of Loulerilio ovidenoed thels oonPotlos that tho coolal atudes ooures aut juatis iteols by the mogure in wich it wete the pects of ohdidren and roung people. by 180 ablist to provlde opportund ties for

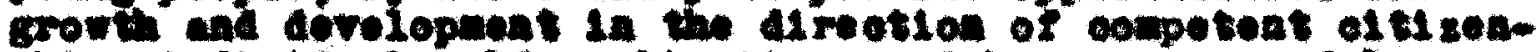
onip, Individun bole roalsetion, and happl sueooserul

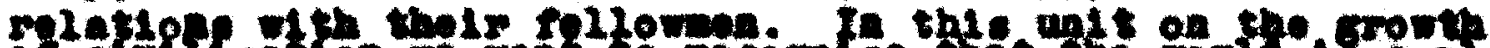

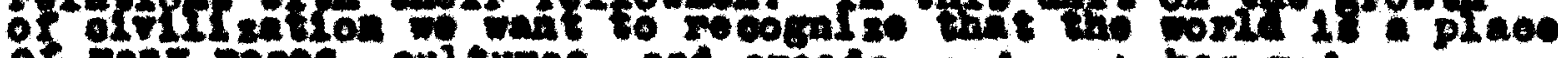
of many rache, oul tures, and orwode, and onoh hat made rocog-

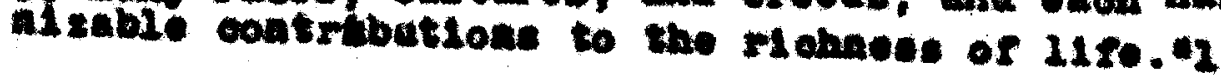


That are the oharapterioties which a cood und of stud chould possoner Firet on tho 1 iet is 145 seopo. The toplo abould bo broad onovich for erery monbor of tho

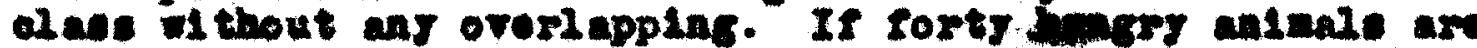

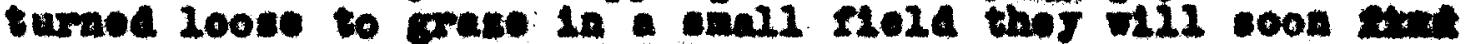

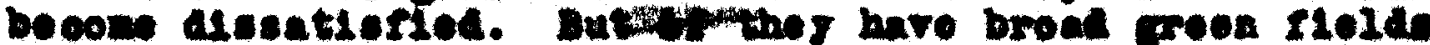

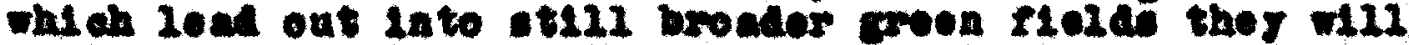
coatver and rood to thelr oompleto anteraotion. Bo it is

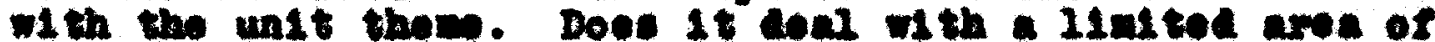
knowledse or does $1 t$ contaln a wie varioty of toples, a -t121 groater maber of inplioation, and an endiose oupply

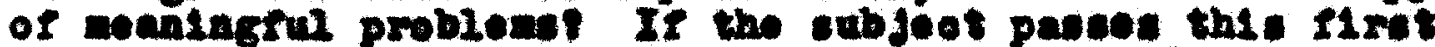
totit it gneraily qualiries in the othor ware."

III Conoral objectives:-

2. To toneh that ofilization has sot alwaye extetod as it is at procent but has ovolved out of conthume change

2. To tonch worid conseloupness

5. To dovelop an intorest in IIfe in othor Iande

4. To roeogalso Man's conmon mode

5. To derelop a erepathot1 uadowetanding of undorpy theeged nations

6. To deverop cameful and opt theal thinkins

7. To dovelop the maning of domooraer we wo belleve in is

IV speatre Objeattres:-

2. To got an oremton of Eespt

8. To oet the atage for the otudy

7 Loerning cotititien:-

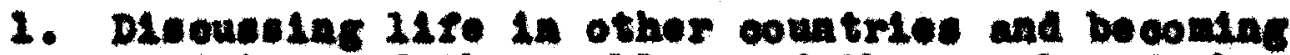
conselout of the probleng of the people of the world nawply, rook, bhol tor, elethins, courelty,

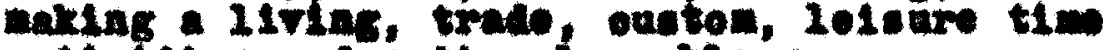
aotivitioe and hatlonal pobions

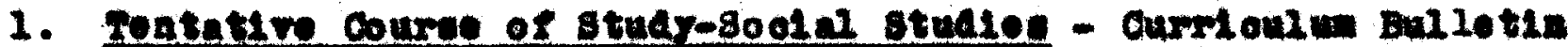

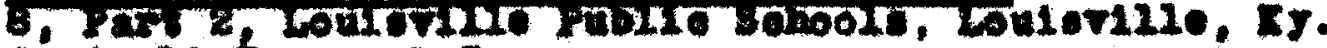
sept. 204 Pp $1-8$

2. 


\section{Junthrigation of Approned to the Unte}

1 Explanationt-

The toacher celeoted the bet plotures

arallable to cover the oubjoes nattor she empotid

to torach.

II Justriontion:-

"Wose a walt has bon abosen the soadber must

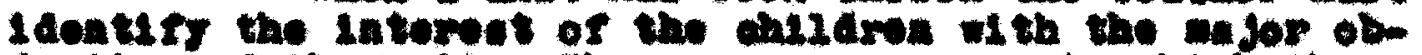

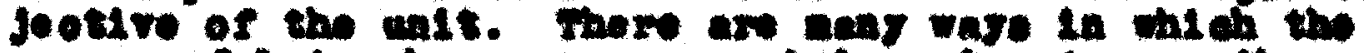

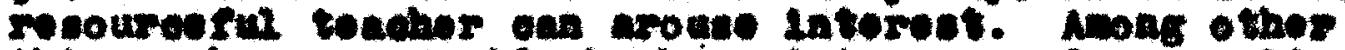
thlpge the on provide booke, pletares, end aome ellpplage whoh wi2l aroube interest. ${ }^{2}$

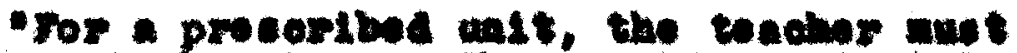

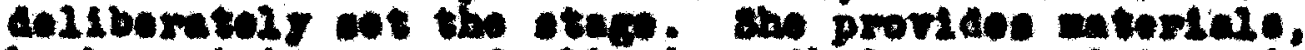
books, ploturwe, ant ellpplige that aroune Intorost In the unl teto-be," 8

III Goneral objeotswer-

1. To entren a intereat in tho 1180 and people of Deppt.

2. To Loviop an ingulatsive und and a colm to otudy the country.

IV Epedrte objectiven-

1. To reopest and eare for proporty (teachere plotures)

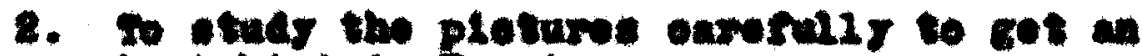
Ineight inte Eopt

$\checkmark$ Learning Motivitiest-

1. Working with rioual matoriale

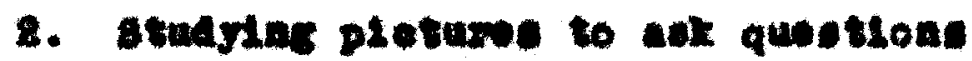

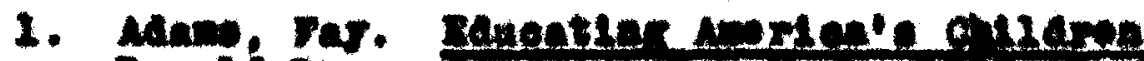

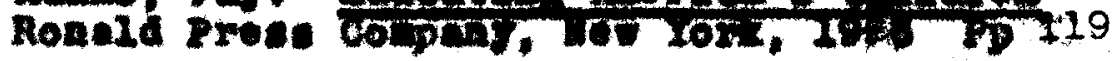

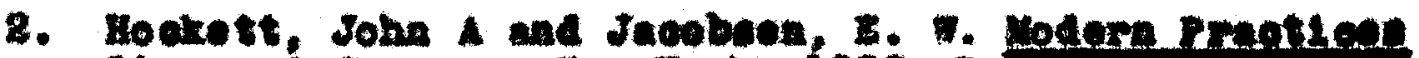

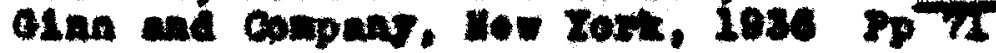


Juntifleation of Group nors in Organisution

1 Explanation:-

After the captain were olouted the nonbors of the croug were choten. An far as poselble onol ohlle was allowe to work in the group that he proferrod. If

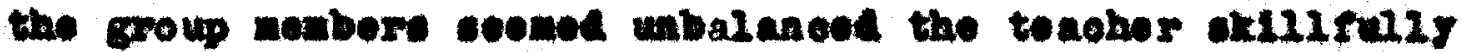
gulded the ohildren into anothor group to keop the numbre workable. The toacher thon talked to onch group Indridualy and Iaformaly. A sound table and well chalre anke a oomfortable cotting for laformal disougaton. the rest of

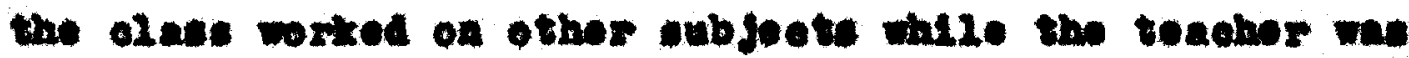
buey of th the erougs.

I Dutsrieation:-

-In oraer to ostabilah a harmonlous atmoupher. ahilaren should be permitted to beleos the tople which intereste then most. Howerur, some problem have a atrons

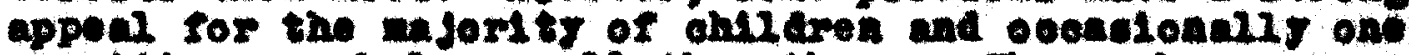
oomel ttes overbulanos all the othork. Those who expreas a cecond preforutes are urtod to equalise the aubers of Group nonbre. At tiwes the toabhor finds horeole using -xport salosmandulp to ont10 a boy out of the history comittoe into los popular tople. Bue nay play it up

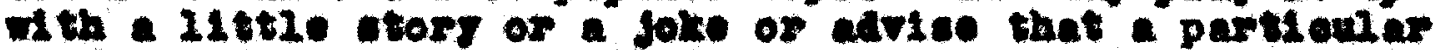
eublect offere opportual ty for greater activity. It nar

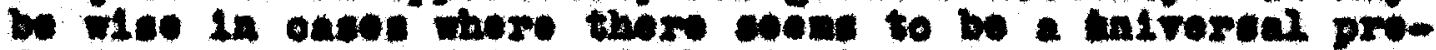
formuce for one or two of the toptes to requent the alest

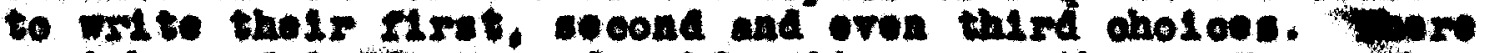

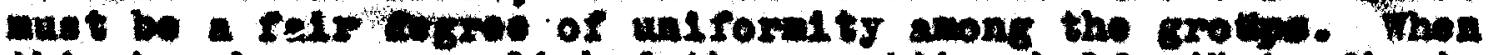

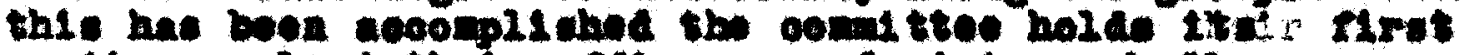

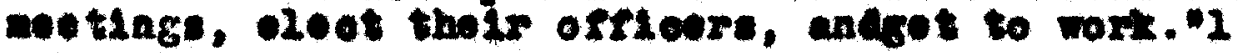

"In mang clanees 11 the guestlone in which the roungotom are interestod are witten on tho board. Thon

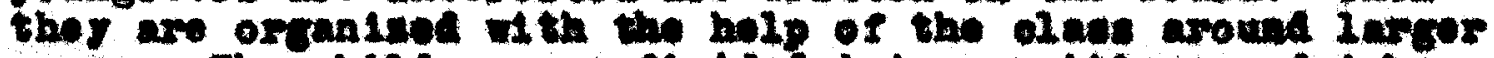

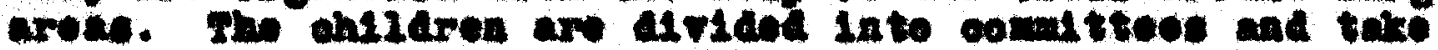
one or more of the laxper problewe to work on. Then the

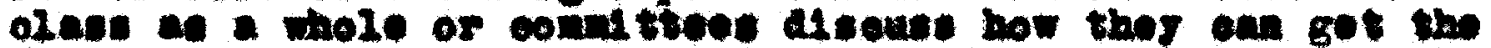

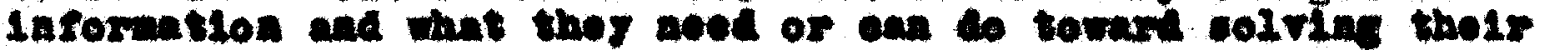

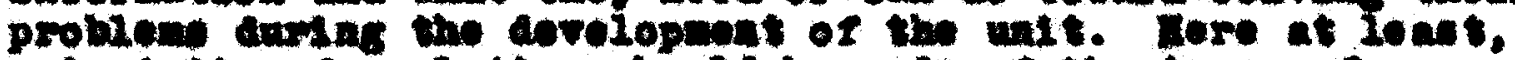

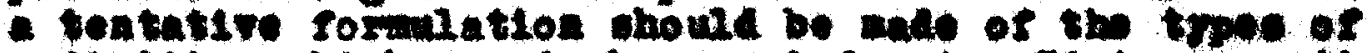

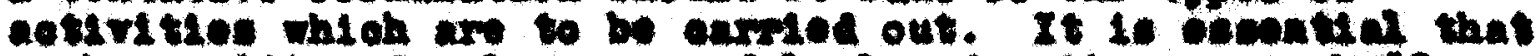

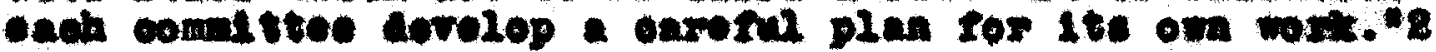


I an not romente onoun about the rowne to

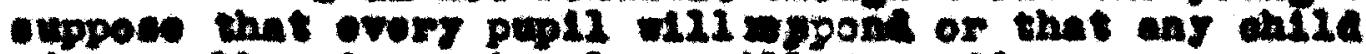

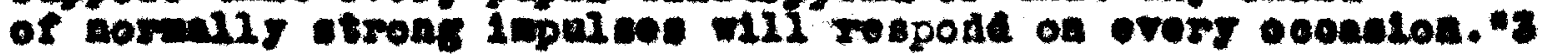

TR ceneras objectwet-

2. To toad by proeops thet through group work

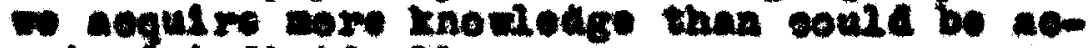
gulded inditanily.

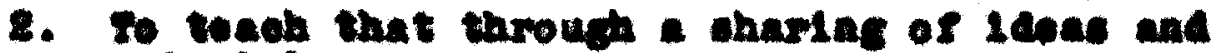
atemale wo rov.

3. Te trad that kolplas othore atron a good

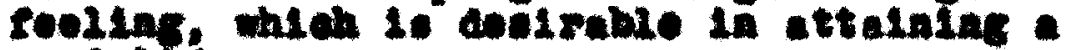
arat $21 \%$.

IT Spodele obgetroer-

1. 20 cooporate, in woritag ath othom.

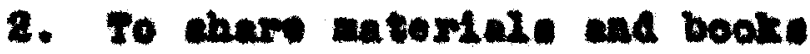

3. 20 arrelop a we varety of mading expetenes.

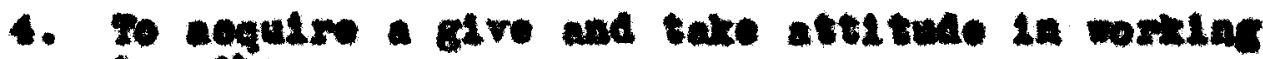
cogether.

V Lenralas cativitient-

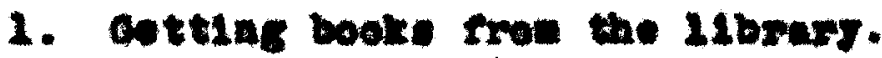

2. Looklag through book at hom for materta.

3. outriac out pletureo.

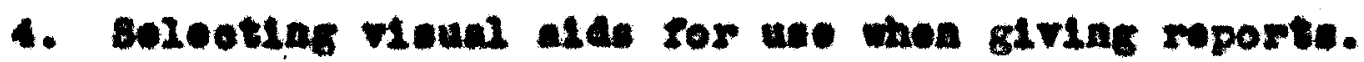

b. Vutar us incormation.

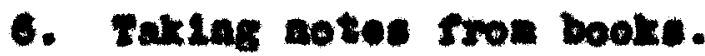

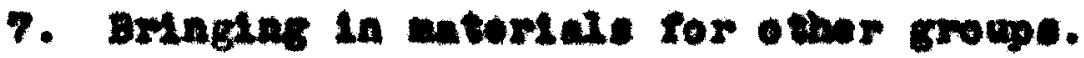

8. Minklas about conerote wro to chor nork to olase.

- Exportmontias ats 1aono.

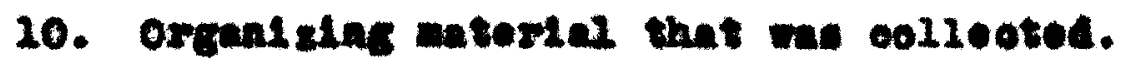

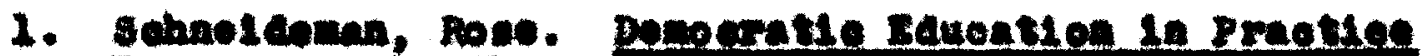

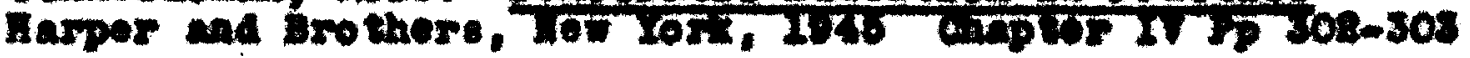

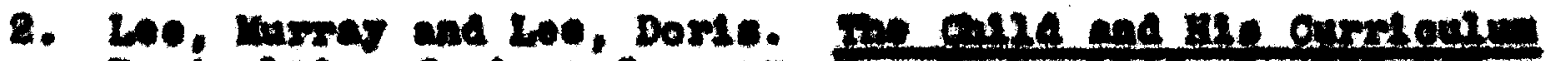

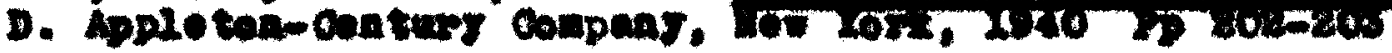

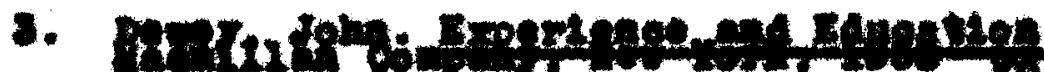




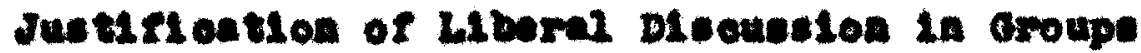

Expanatloni-

At al tine duplag the atsouselon pertod

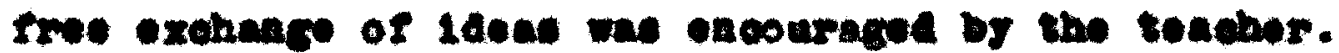

Each pereon wa cllowed to ger hle owa rlewe on the

oubject and his laoes wore recelved by the troup.

In one of the croups the prollon of Ingande oxplosting tho Ecrptsen peoplo in cotton production vas

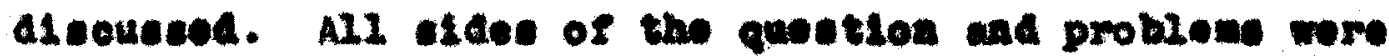

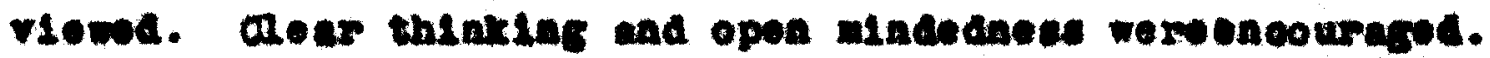

II Justirlontioni-

- Hany sociel problone have thalr moote doep

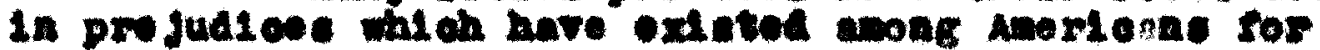
genoratione, pasued along fron parons to ohild ac pare ot how sralning. The cobol has row grout obligation

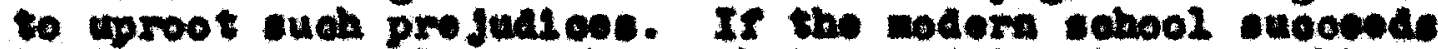

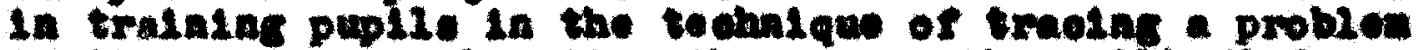
to 1to soures and lockting the aaves, ther will fiad a war to grapple ol th obstades in the war of armirias at a colution. Durlag the procese thor alil noqulm a senes of

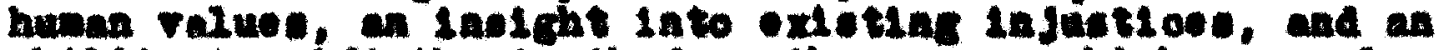

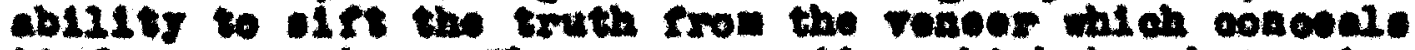

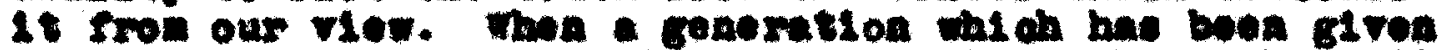
this lind of trainiag arrives at the plase where the 1112 be permitted to ast, thore -111 be cole reseon to bope for

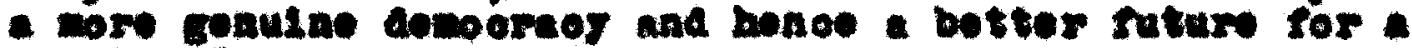
country." I

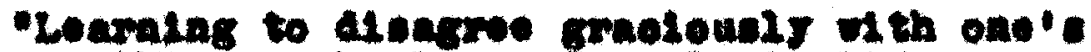

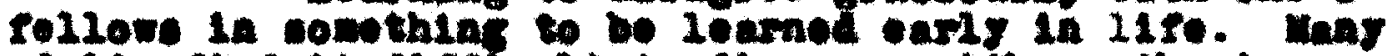
aduite rind it diffiout to alengres ol th another's opinlone in an aftiable, plesent waner, tho troedisousion group le a good tralaling ground for oourtwous atsagrocenate. "8

III Gonoral Objoettree:-

1. To dovelop en opon alnd on controverstal questone

2. To dovelop inttiative in soarohing for woro anterial on the subsed 
3. To get information from different courees

4. To encourage a exee exphange of lidea

IV Speolf1e Objeotiven:-

1. To toach how to ake and use a b1bllography

2. To toech the subject mattor connooted with the undt

7 Learaing Aotivitiea:-

1. Spearing froely in a group

2. Showing 1does

3. Thinklag about Ierpt's working elase of peoplo

4. Comaring a liborer in Igrpt with one in Amrite

b. Telking about frocdon and tho domoeratio way of 11fe

6. Talking about Bod and the Ton Conmendmonte and the Colden Rule of lite

1. Bohneldonan, Roce. Devocratle Eduoatlon in Preotles.

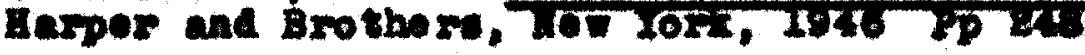

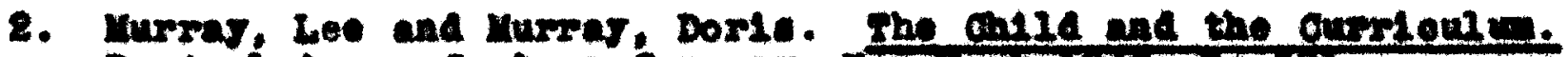

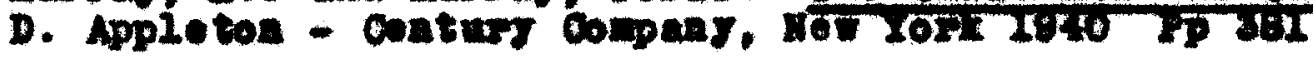




\section{Just1fication of Trips}

I Explanation:-

The ontire group wat to the mate hibrars.

Atre we found the bookn wo noved and riektod the

ancow.

II Justifleasloa:-

"Xxipe are raluable sor rovealing as wil as for arouning and atreagthoning lateroset. Thos give the teachor exeszlont opportunities to obminohizaren and note tho thinge that ohnilonge thelr attont1on. mor ax exeeliont moane of cotting cequedatod and of billeles grous solidarity. They have tholr place in tho initial stage of an wadortaring.

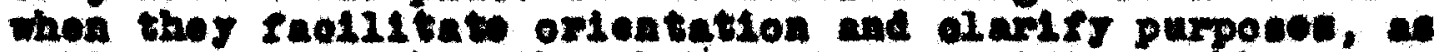
w12 as later, whon they help oolve opecifle problend, or at the conoluolen, when they way serve as en Intograting cumary." I

Ixt General objoct1ves:-

1. To boneclous of our onvironment - notlug the good thinge in 1t, and tring to rigure ont or plan waje to Inprove wak polnte.

2. To becoln better aequalited wh onlieren in the alase.

IV speolrie objectivei-

1. voling our library faolistios.

2. Lorrelng to be indopondont in cotelng books and pletures.

8. Cooperating inth other ahliarea.

4 . gharting of booke and ldon.

7 Loaraling Aotiritios:-

1. Oberiar the eafety mules in colac to the

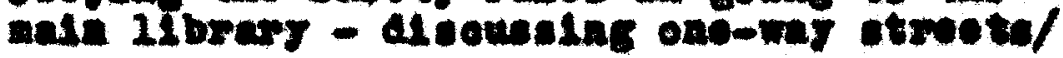

8. Loarniag the name of tho otwoest on the war to the IIberary.

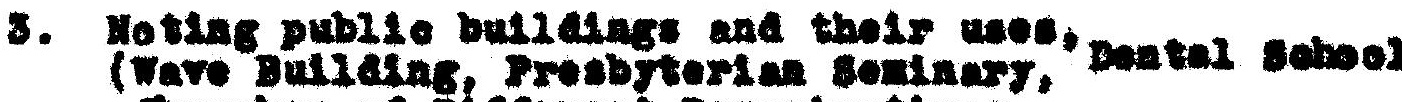
Durreber of Dlfroront Denoulnatlons,

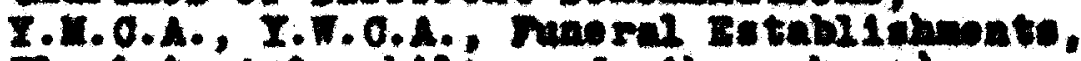
horiet, Aurombile, and other shopel 
4. Learaing how to wee the $11 \mathrm{brary}$.

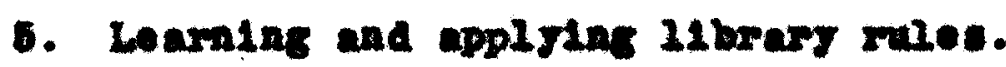

6. Loaralas by pules are accosentr.

7. Viel tzac our meoun.

- Holpleg to solve our problems by ceeing. reading and Lietening.

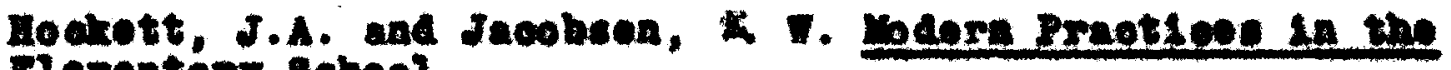
Hementer Bahoel.

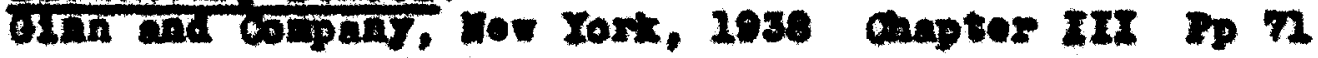


Justifioation of Creative Art and i Varlety of Exporiences

I Explanation:-

Whon the Soolal stiediea perlod came, the teacher allowed three groupe to work at one time. The teacher consulted with eaob group to nake sure that eaoh ohlld was working to the best of his ablilty. The group oaptain mado a dally progrese abock to see that each on in his group was ading conthing worthrile to his group aotivity.

When the oreative activities were in full owing $1 t$ was often necessary to allor just one group to "oreate". It is here that good organization is neoded, and thorough knowledge of the "how" in all phases of the work is neceseary. The ok11lful toacher w11 try hor hand in modeling, in making a puppet, in drawing flguresand in all phases of construotion before she turna the work over to a group. It is true in upper elementary grades that rery often the oreat1ve, artietie ohild wil surpass the teacher in the finished produot. And very often the teaoher too learas "new" way or a "shart out" or a "better" way to perform an aot. This 1a all well and doelrable. To at learn by dolag, and if education 18 experience, each new tank undertaken w1I add growth to our make-up. It is dealrable to have a variety of oreative experiences to satiefy the nornal individual differenoes that ariae in every group.

II Juet1fioation:-

"Tron the coofal polnt of riew as contrasted with art for art's sake, the probien of art like tinat of roligton and rooretion, turne today on 1 te cervice to nan 1n his laner adustaent to an environment which ohifte and changes with unexalpled rapidity. It appeare to be oae of 
three groat forees which stand between malajusted man and his breakdown. Each serres in its own way to bring h1m comfort, corenity and joy."1

\section{- Greativenese conelate of eelf expression}

whioh for a given indifudual is new or is an improvenent over his provious oreative aote. An aot is creative if, for a given 1ndividual, it 10 unique and original, oven though such an aot has been performed by chlidren of his age group for onturies pact. Greativenese 18 to be Judged not by 1 ts prokuef but by the procese going on within the oreator." 2

Un1t eot1rity groups aro organizea on the bas 18 of unterest in cone particular angle of a cubjeot. Whon the group is aceabled postions in 1 t will be establichod by indirianal the pupil wo is the ade whenwhe plan calls for researan 1s not neceesarily the leader when the fine arts are in progmese. Consequently the sam group of $1 x$ children may have elx leader if

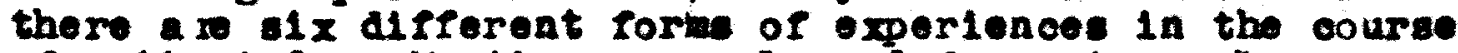
of unit study. Hetinge ere planned for art, musio, oonetruotion, oreative writins, sewing, trpemitins, danolns, te. There are this opportunities for all to lead as well as to follow."

The wide range in ability and achievoment with1n the older group nake differentiated worl eseential. Glfted ohildren need to be challenged with 1 deas and opportunl 1 and guided into naring rormilis individual contributione. Rotarded ohildren need opportunities to worl on the ans toplos with others, but to road on there on levels and to do thinge which they oan do with protit for therinelves and othere."4

- All subject fielde are enriched by art in aotion, that 1s. by art in the surroundinge and in ohildron's reaotlons. Soclal studies are made virid and are enotionalixed through art. Murale, posters, drantized coones are exprese17e both of the inpresions whioh ohildren have gained and of their ow feeling for the subjeot under consideration. Art has been aptis temed the handmalden of all the aotivity of the elementary olaesroon." 6

III ceneral objectives:-

1. To teach that each Individual has within hin latent talente that are worh developing, and that w mat reepe ot our nelgivesus talents as wil as our own.

2. To respeet work with the hands.

3. To try to develop okill in handilng alferent

4. To appreolate a tak weIl done. 
- To try to dovelop the laen that each one ond nake contribution to the group that 1111 , make the group work riaher

6 To share exoative expertences

IV specte10 Objeot17os:-

1 so derelop axill in codeling puppete for tho puppet now

2 To awaken the Individual in notiolng charactorietios in alfferent people to nake puppete more individualistio

3 To derelop ak121 in drawing aural and coelng the aoning of cequence in plotures

4 To give belp whon poselble in the conetruotion of the thestre, mubeus, ote

- To dovelop InItintive in planning and oarrying out leses

$\checkmark$ Loarnias Motivities:-

1 uxing alar for puppet's hoade

2 Beslgaing and soulas costume for puppote

3 Palnting soenory for puppet show

4 Nriting the plar

- Blanning tho aured

- Draving the mural

7 Palnting the nurel

- Bullatro a neoun

- Modoling bouls, other pottery

20 Making wapons

21 Making fural ture

12 Drescise a momy

23 yodoling a sphinx, prranles and obel1aks

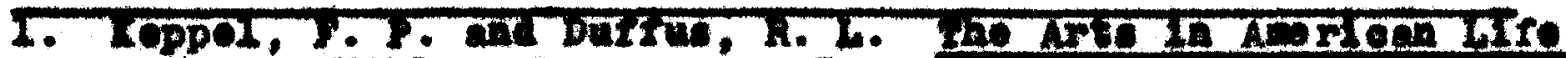
Moorax - HLil Book Colpany, Ino., LOt lorx, lobs ip aby 


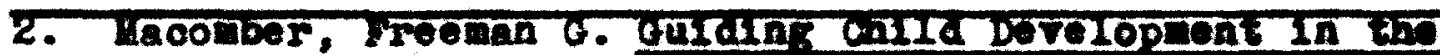

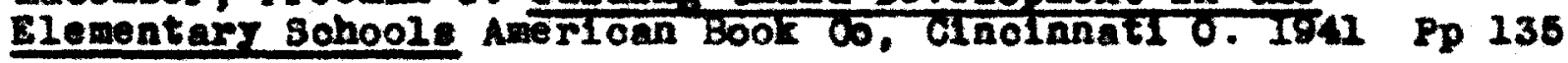

3. Sohne1deman, Rose. Depooratie Edueation in Prootioe Harper and Brothers, 207 lor, 1046 Pp 308

4. Strlakland, Ruth. Bow to Butld a Unit of rot Bulletin Ho. 6,1946 Fodera seourity Agenoy, U 3 offlce of Education.

5. Baxter, Bernioe and Bradley, Anne. An Orerrier of Eleneatary Eduoation D. C. Heath and Company, Boston, Lass. 1946 Pp 94 


\section{Jutifloation of Comunity Use}

I Explanation:-

An ex-G.I. came to the school and told the olase of his experienoe in Northern Afrloa. He told of his trip to Afrion, the olsmate, soll, heriehipe, IInds of people he net, the natives, trade with the netires, Interesting sighte and sowe of the things about Army 11 fo. He is atudent and also put in a good word for higher education. He 18 an atb lete, and made quite an impression on the clase. H1s risit was rery worth whie.

II Justifloation:-

"Whothor a comund ty is partiourarly mich in hietorloal background or not, it is surprialng wat a wealth of insorration, contaots 1 th people, and reasaroh w11 unfold, Tho ontaot with adulto made in planning. organising, and onrying out such progran isproves the quality of learning."

III Ceneral objectives:-

1. To Learn fron other's experienoes

2. To respet another's riew point

3. To leara how wo treat gueste

4. To alsouse the value of travel

IV Speolf10 Objeotires:-

1. 2o give firet hand information to alase about the country of Egrpt

2. To appresiate the contribution our visitor nakes to our und

$v$ Learaing sotirities:-

1. Listening with interest

2. Being polite in an audenoe

3. Questloning to clarify a polat 
4. Showing work to the visitor

o. Expressing our gratitude for the talk

Orranlelng the klenentary Sohool for Lring and Leaming I947 loarboor, Ansociation for Supervialon and Currioulu Developmen: of the Hatlonal Eucation Assoolation

1201 16th street, N. W., Washington, D. C. P, 27 
I Explanation:-

At an opportune tine Anding the growth of the unit, woring plotures were shown that dealt with a partloular phase of the rork, namely, the desert and the 111. Valley. The plotures shown were Desert Patrol and EgJpt, Kingdon of the Mile.

II Justisioation:-

"The motion ploture, as such, 1s potent medium of eduoation. Children even of the cariy age of elght see half the faots in a ploture and remember then for a urprisingly long t1m. A single exposure to ploture nas produce mosurable change in attitude. Emotlons are moasurably stimred as the soenos of a drana unfold and this exol toment may be reoorded in dovlations Irom the norn in sleep pattery by visible grose evidenoes of bodily morement and by reflaed laternal responses. They conel tute patterne or oonduot in day dreaning, phantasy and action: The evidence of the 1 r Influenoe is masive and irrefutable."

III General objeotives:-

1. To gain a rioher and fullor background of EgJptian 11fe

2. To observe ruled of good conduot in an aduienoe situation

3. To enjoy moviea

IV Speolf10 Objeotions:-

1. Desert Patrol - To show:-

(a) Irrigation by punps and buckets

(b) Ghildren owloming in a water hole- on on ogsi:

(0) The women dolng their housohold dutles

(d) The womon olosalng and oplnning the halr of the dromedarios

(0) Wind-blown sande of the desert

(r) The oamels rollning during and storm

(B) Oas1s with the cent1nel standing guard 
2. Egspt, IIngdon of the H110 - To show:-

(a) Present view of Bept

(b) The historlo N110

(o) The boate at the water's edge

(d) The city of Luxor and the temple

(e) The ralley of the kings

(5) The N12e with the wowen walking in the hallow watere oarrying Juge

(8) Scenes of the ox-powered water pumps

(h) The pyramide and tho sphinx

V Learniag Aotivities:-

1. Hoting the points of elmilarity and oontrast with our own country

2. Oberering the land, the drese, the oustome of the poople, to.

3. Finding joints of interest in the ploture

4. Enjojing the ploture 
I Ixplanat1on:-

1 dete was cot for the Culninating Progran and each group was roady to give hia part. The group oaptaln ade up his program. Thore wero oral reports, written roporte. storien and the Ilnal howing of tho hadioraft and crotive aotivitios. Parents were invited to the progran. Mnotber olase in the bullaing was invited.

II Jutifloation:-

Tho connotation of the work oulmination,

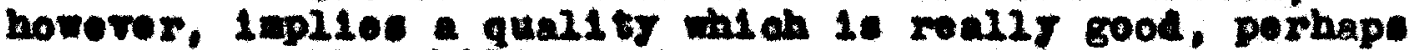
great. Tor the ahilaren thore is a oortals anount of Glamour in a culminatine aotirity. While thes axe striting to graep the laees and the onotlons aoquirod by mans of unde etway, thor are building up to a olimax,

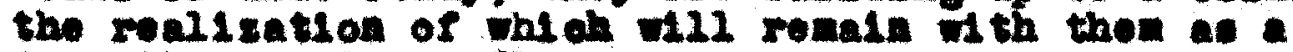
drandb experienos." 1

"Through such progran as th1" the parents not only hare cow to understand the chool better, but they have ass istod of ton and very materialiy in our efforto at ourrioul w aking through a erpathot10 understandine of what the obool has been attoupting to do. Through the tual of the methode of modern eduoation paronte are able to harmonise thoir contributione to tho cduoation pf thile chlidren with school contributions." 2

III Goneral objeotives:-

1 To corer the oubjeot matter wet forth an dealrable to toach good ol ti genchip

2 To bring to a entiataotory cloce a unit of wowk

s to aequalat parente with the sohool and 1ts phllosophy

IT Epeciflo Objoot17os:-

1 To have a worthinlle progran that inoludes orery oblia in the room

2 To develop a feellag af growth in sadh Iadriduni

3 To allow the parente to wee the final oreatione that the onildren have been talking about and working on 
4. To have pleasure in giving a program for visitors

$\nabla$ Learning Notivities:-

1. Groeting friende

2. Taking part in a progran

3. Haring pride in an acoomplishment

1. Schneldonan, Ros Droorat10 Rduogtion In Praotioe Harper and Brothore, Hot York, 1945 PP 316

2. Tippett, James $s$ and Othore Currioulum Making in an Elementary Sobool Ginn and Company, New York, I9ZT Pp 361 
Justification for Criteria for Evaluating Aotivities

I Explanation:-

subject matter teste can easily be given to cheak the information and knowledge galnod from the etudy. The teaoher oan al ao note the progrese made in the language arte; epecially in the oral and witten English, the ok11le In spelling and the arl thmetioal progrese.

The true test however, 18 in the fleld of Intanglbles that no one can test. The foelinge for good w111 that have been touched, the seede for the searohing of truthe that have plantod, the practioe in the art of aeoepting difference with an ldea of learning from then, and the rine eplrlume working with, and for ach other. All these, are the real teste of learning in a demooratio society.

II Juatifloation:-

"What changes have ocourred in youngetere as a resul of the unite This question must be answered if the teacher 2 fumer 18 to eraluate the unit. obriabsly, the question 18 whoh broader than oan be deterinined by a pencil and paper test. Yot it 1s the two common practioe for teacher to give a test corering the faotual information taught in the unit and feel that an evaluation has been made." 1

1. Taluation nust alway be in terme of real purpose on the part of the learner/ It is only valla to the extent to whioh it 18 useful in 1mening 1 earning. In so far as eduoation is conoerned the developient of human being is the goal. The actual extent to which wo read that goal oan be derinitely etated by no one on earth. The best we can do 18 to wake judgmente as to what is nost and least holpfal in a partioular situation."2

III General objectires:-

1. To review the unit traidstin the l1ght of goale achleved to see horthwhileness of projeot

Ir Spealfio objectives:-

1. To test the unit and make plane to correot An t iftake in order to have a nore desirable 
$\nabla$ Learning Aotivities:-

1n the unit:-

The following goals were achlered

1. Evidence of awarenese to environment

2. Hablts of orltioel thinking and taplysis

3. Ab111ty to plan with others and to assume responsiblilty for oarrying acoopted task. to completion

4. Hab1t of rerifying statements with substantiating proor

5. Constantly increasing ability to find and to use pertinent information

6. Frer wldening knowledge of places and pooplea, mannere of 117ing, and cultural baokgrounds. Th1s inoluded an interprotation of maps and globes

7. Developing understanding of soolal lnstitutlons and thoir functiona

8. Inoreasing roallzation of waye in which the present is an outgerowth of the past

9. Orowing understanding of man's use of solence In weting the problons of wather topography and natural barriers to trade and communication

10. Appredation of contributions of others:peers, oomunity menbers, persons of other oultures and other nationalities

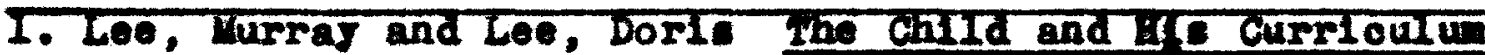

D. Appleton-Century Company, TeV IOIE, I970 Pp 218

2. O1Lee, H. H. Teeoher - Pupll Planning

Harper and Brothere, Mev Lort, L9xI

Pp 109 


\section{Cupter IV}

Conoluston

When the toacher hal suceserfuily completed a unt of work, has been consalous of the many oreative 1eseons involva, and has achered satiafaction in ito cumulative progran, whe $\mathbf{1 1 2}$ begin to reap some of the rewards of her efforts.

By further analyelig her work the way see hor pup1ls growlig in personality and oharacter, whe may noto many dosirable soolal attitudes, now Interests, - In fact, all those Intangibles wht ah akte for good 1150 w211 be mankrostod.

Problng further into the outcowe she war find puplis woriling with sore senl, nore dorotion, and conoentration; they w112 have read more wiely, and roluntar217, and the metery of aki2l, learnol with a purpose, w111 be greater than If thes poselvely relled on teacher dreotion and external motivation. If 1 t has done nothing but otinulate ohliaren to seek furthor knomledge on tholr orm indtiative it is worthinlle, but, in addition, if it nakes both seacher and pupl2s happler and bettor adustod human belage it seoms of value. 


\section{B1bllography}

1. Adams, Fay. Eduoating Amoricale Chlldren.

Ronald Prese Coupany, New Yor,, 1946.

2. Baxter, Bernice and Bradley, Anne $M$. An Orervier of Elementary Education. D.C.Heath and Company. Boston, Mass. 1945.

3. Bobbitt, Franklin. Curriculum of Nodern Eduoation. MoGraw-H111 Book Company, Hex York, 1941.

4. Burton, Vm. H. The Guldance of Learning Aotivities. D. Appieton-Century company, ken Yorर, 1944.

b. Bode, Bojd H. How We Learn. D.C. Heath and Company, Boston, Mass. 1940.

6. Bode, Boyd H. Demororaey as a Way of Life. Maomilian and Company, Hew York, 1937.

7. Callfornia state Currioulun Comilssion. Feacher's Gulde to Child Derelopment in the Intermediate Gradoe. state Dopartment of Eduogtion, sooramento, Callfornia. 1936.

8. Charters, M. Motion Plotures and Youth. The Macmilian companj, Vow Lork. I9s5.

9. Derey, John. Experlence and Education. The Mackilian Company. NeW York, 1936.

10. Gates, Arthur and Others. Educational Psyemsegr. The Macnilian Company, New IOTK. 1942.

11. G110s, H. I. Teacher-Pup11 Planniag. Harper and Brothera. How York. I94I

12. E1I areth, Gentrude B. Learning the Throe R's. Educational Publishers. Philadelphia, Penn. I936

13. Hookett, J. A. and Jaoobsen, E. N. Modern Praotioes in the Elenuntary 8ohool. New Edition, olnil and Company, Ven lorर, 1943.

14. Keppel, F. P. and Duffus, R. L. The Arts in Amerioan Life. MoGraw-H1Il Book Companj, How YorT, I933.

16. Lane, Robert H1II, and Othere. The Progrosel re Elementary Sahool. A Handbook for PrinolpeIs, Toahors, and Parente. Houghton Mfrlin Company. Boston, Mass. 1938

16. Lee, J. Murray, and Lee, Dor1s Lay. The Chlld and H1s Currioulun. D. Appleton-Contury Companj. IOT York. 1940.

17. Moomber, Froeman o. Gulding Child Development in the Elementary Sohool. Amerioan BoOK Companj. Hon York. I941

18. Moree, Paul. Language in the Elementary Sohool. Houghton-14fritn companj. Boston, iass. 1939

19. Moarne, Hughes. Creative Youth. Double Day, Page and Company. Hew York, I9Z5. 
20. Mational Education Assoolation, Department of Supervisors and Direotors of Instruotion. 1940 Yearbook. Newer Instruotionel Praotioes of Pronise. The Assool ation, lashington, D. C. 1940.

21. National Education Assoclation, Department of Supervision and Currioulun Development. 1944 Yearbook. Toward a Ner Currioulun. The assoolation, Fashington, D.C. 1944.

22. National Eduoation Assoolation, Department of Flementary Prinolpals. Twentieth Yearbook: Language Arte in the Elementary Sohool. The Association, Washington, D. C. 1941.

23. National soolety for the study of Iduestion. Th1rty-e1ghth Yearbook Part I: Ohild Derelopeont and the curri oulua. Pubilo school publishing company, Bloonington, Indiana. 1939.

24. Sohneldeman, Rose. Democritio Education in Practice. Barper and Brothers. Wow York. 1945.

25. Strang, Ruth May. Introduction to Child studr. The Maomilion Companj, New York. 1938.

26. Striakland, Ruth G. Hor to Bulld a Ualt of work. Bullotin No. 5, 1946. Tredral socurity Agenoy, U. S. Offlce of Education.

27. Tentative Course of study - Soc1al studies. Curriouin Bulletin 8, Part 2, Louls rille Publle sohools. Loulavilie, Kentuoky. Sept. 1947.

28. Tippett, James S and Others. Currioulum Making in an Elomentary School. Ginn and companj. low rork. IgLT. 